\title{
Knowledge on Pressure Ulcer Prevention Among Nursing Professionals ${ }^{1}$
}

\author{
Margareth Yuri Miyazaki \\ Maria Helena Larcher Caliri ${ }^{3}$ \\ Claudia Benedita dos Santos ${ }^{4}$
}

This study aimed to describe and to analyze knowledge on pressure ulcer prevention among nursing team members working in direct care to adult and elderly patients at a university hospital. A descriptive and exploratory research was carried out between January and March 2009, after approval by the Research Ethics Committee at the study institution. Data were collected through a validated questionnaire. Participants were 386 professionals, of whom $64.8 \%$ were nursing auxiliaries/technicians and $35.2 \%$ baccalaureate nurses (BSN). The mean percentage of correct answers on the knowledge test was $79.4 \%(\mathrm{SD}=8.3 \%)$ for nurses and $73.6 \%(S D=9.8 \%)$ for nursing auxiliaries/technicians. Both professional categories display knowledge deficits in some areas related to the theme. The identification of deficient areas can guide strategic planning with a view to the dissemination and adoption of prevention measures by the team.

Descriptors: Pressure Ulcer; Evidence-Based Nursing/Education; Nursing, Team.

\footnotetext{
${ }^{1}$ Article extracted from Master's Dissertation "Conhecimento das recomendações para a prevenção da úlcera por pressão pela equipe de enfermagem de um hospital universitário", presented to Escola de Enfermagem de Ribeirão Preto, Universidade de São Paulo, WHO Collaborating Centre for Nursing Research Development, SP, Brazil. Supported by Conselho Nacional de Desenvolvimento Científico e Tecnológico (CNPq), under process n. 305539/2008-6 Productivity Grant holder (brasilian type of financial support).

2 RN, M.Sc. in Nursing, Professor, Universidade Paulista (UNIP), Campus Ribeirão Preto, SP, Brazil. E-mail: myurimiyazaki@yahoo.com.br.

${ }^{3}$ RN, Ph.D. in Nursing, Associate Professor, Escola de Enfermagem de Ribeirão Preto, Universidade de São Paulo, WHO Collaborating Centre for Nursing Research Development, SP, Brazil. E-mail: mhcaliri@eerp.usp.br.

${ }^{4}$ Ph.D. in Statistics, Associate Professor, Escola de Enfermagem de Ribeirão Preto, Universidade de São Paulo, WHO Collaborating Centre for Nursing Research Development, SP, Brazil. E-mail: cbsantos@eerp.usp.br.
}

Corresponding Author:

Margareth Yuri Miyazaki

Universidade Paulista - UNIP - Campus Ribeirão Preto

Av. Carlos Consoni, 10

Jardim Canadá

CEP: 14024-270, Ribeirão Preto, SP, Brasil

E-mail: myurimiyazaki@yahoo.com.br 


\section{Conhecimento dos profissionais de enfermagem sobre prevenção da úlcera por pressão}

O objetivo deste estudo foi descrever e analisar o conhecimento dos membros da equipe de enfermagem que atuam diretamente na assistência a pacientes adultos e idosos, em um hospital universitário, sobre a prevenção da úlcera por pressão. Trata-se de estudo descritivo-exploratório, realizado entre janeiro e março de 2009, aprovado pelo Comitê de Ética em Pesquisa da instituição. Os dados foram coletados por meio de um questionário validado. Participaram deste estudo 386 indivíduos, $64,8 \%$ eram auxiliares/técnicos de enfermagem e $35,2 \%$, enfermeiros. Vê-se, pelos resultados, que a porcentagem média de acertos no teste de conhecimento foi de $79,4 \%$ ( $d p=8,3 \%$ ) para os enfermeiros e $73,6 \%(\mathrm{dp}=9,8 \%)$ para os auxiliares/técnicos de enfermagem. Conclui-se que ambas as categorias de profissionais apresentam déficits de conhecimento em algumas áreas referentes ao tema. A identificação das áreas deficientes pode nortear o planejamento de estratégias para disseminação e para adoção de medidas preventivas pela equipe.

Descritores: Úlcera por Pressão; Enfermagem Baseada em Evidências/Educação; Equipe de Enfermagem.

\section{Conocimiento de los profesionales de enfermería sobre prevención de la úlcera por presión}

Este estudio tuvo por objetivo describir y analizar el conocimiento de los miembros del equipo de enfermería, que actúan directamente en la asistencia a pacientes adultos y ancianos, en un hospital universitario, sobre la prevención de la úlcera por presión. Se trata de un estudio descriptivo-exploratorio, realizado entre enero y marzo de 2009, aprobado por el Comité de Ética en Investigación de la institución. Los datos fueron recolectaos por medio de un cuestionario validado. De los 386 participantes, $64,8 \%$ eran auxiliares/técnicos de enfermería y $35,2 \%$, enfermeros. El porcentaje promedio de aciertos en la prueba de conocimiento fue $79,4 \%$ ( $\mathrm{de}=8,3 \%$ ) para los enfermeros y $73,6 \%$ (de $=9,8 \%$ ) para los auxiliares/técnicos de enfermería. Concluimos que ambas categorías de profesionales presentan déficits de conocimiento en algunas áreas del tema en referencia. La identificación de las áreas deficientes puede orientar la planificación de estrategias para diseminación y adopción de medidas preventivas por el equipo.

Descriptores: Úlcera por Presión; Enfermería Basada en la Evidencia/Educación; Grupo de Enfermería.

\section{Introduction}

Nowadays, tertiary hospitals deliver care to increasingly critical patients and with higher complexity levels due to the greater survival of patients with chronic illnesses and traumas. In these conditions, these individuals are more susceptible to complications that put their safety at risk, including hospital infections, medication administration errors and injuries to skin integrity, among others. On the other hand, patients are increasingly aware of their rights to receive high-quality care and are more demanding regarding the products and services offered by health institutions.
These institutions, including university teaching hospitals, have used different strategies to face these questions, such as the creation of Quality Improvement Programs, Patient Safety Committees and other initiatives aimed at qualifying the care offered and to investigate the state of certain quality indicators.

With regard to injuries to skin integrity, pressure ulcer (PU) in hospitalized patients represents an important problem, due to the high ratios found and the emotional and financial costs they entail. PU entails high costs for the patient, family, hospital, health institution 
and society as a whole. This condition demands continuity and extension of care beyond the end of hospitalization. It entails socioeconomic consequences for the country and the health system, as it increases morbidity and mortality, impairs the patients and families' quality of life and generates more spending on resources that often are already scarce si-3). $^{(1)}$

In order to reach care with quality, various authors have been highlighting that nursing professionals need scientific knowledge related to PU, as practice very often is not based on evidence but on myths, traditions and one's own or colleagues' experiences ${ }^{(2,4-6)}$.

In the international sphere, there are various clinical practice guidelines, with orientations for PU treatment and prevention, use of interdisciplinary approaches and educational programs with a view to the implementation of evidence-based practice ${ }^{(7-10)}$. In Brazil, so far, there are no national guidelines for PU prevention and treatment. Despite the increase in studies and publications in recent years, these are not sufficient to propose different recommendations than what already exists at international levels. Experts in the area use international guidelines to establish recommendations for Brazilian health scenarios ${ }^{(1,3)}$.

Implementing clinical guidelines in practice is not a direct linear process, and their use is more probable when certain factors are optimized(9).

In literature, studies on nurses and nursing students' knowledge on PU prevention and treatment demonstrate that knowledge levels are associated with some individual and educational characteristics(1,5,11-16).

A review of these studies shows that, despite technical-scientific advances in health and guidelines with recommendations for $\mathrm{PU}$ prevention, the problem persists around the world, and nursing professionals' knowledge remains deficient. In a bibliographic survey carried out in the LILACS (Latin American and Caribbean Health Science Literature) database, no publication was identified in Brazil which investigated knowledge for PU prevention in a broader sense, including professionals from different nursing categories and hospital Units.

In the attempt to contribute to knowledge advances in this area, this research was done with nursing team members from a tertiary hospital in an inner city of São Paulo State. The goal was to describe and analyze the knowledge of nursing team members working in direct care delivery to adult and elderly patients regarding pressure ulcer assessment, classification and prevention.

\section{Methods}

Approval for this quantitative research with a descriptive-exploratory design was obtained from the Institutional Review Board of the institution where the research was performed. The nursing staff working in direct care to adult and elderly patients at the hospital comprised 158 baccalaureate nurses (BSN), 49 nursing technicians and 450 nursing auxiliaries. The researchers decided to contact all 158 nurses, as data collection could include all subjects in that category. Sample size for the nursing auxiliary/technician category was determined randomly. With $a=0.05$ and $\beta=0.10$ and correcting for a finite population, the ideal sample in this category would have 217 nursing auxiliaries/technicians. In view of possible losses in data collection, estimated at $25 \%$ in the pilot study, the number of professionals to be drafted was set at 289 .

Data were collected between January and March 2009, using an instrument with items related to sociodemographic data and a knowledge test called Pieper's Pressure Ulcer Knowledge Test (PUKT), validated and adapted in a previous Brazilian study(1).

The goal of the knowledge test was to measure the participants' knowledge level on the recommendations for PU prevention. This test is based on the recommendations proposed in international guidelines and comprises 41 true-or-false assertions, with eight items on PU assessment and classification and 33 items on PU prevention.

For each of the assertions, the participant should select an answer among True ( $T$ ), False (F) and I Do Not Know (NK). Each correct answer corresponded to one point. Correct answers corresponded to true assertions answered with $\mathrm{T}$ or false ones answered with $\mathrm{F}$. For wrong or NK answers, the score was zero. The total score on the knowledge test was the sum of all correct answers. In the original study, participants were expected to give $90 \%$ or more of correct answers for knowledge to be considered adequate ${ }^{(11)}$. In this study, the researchers decided to present test results in score ranges of $90 \%$ or more, between $70 \%$ and $89.9 \%$, between 50 and $69.9 \%$ and below $50 \%$.

The instrument was distributed to those subjects who accepted to participate and signed the Free and Informed Consent Term. Participants answered individually during work hours and returned the test to the researcher immediately in an unidentified envelope, so as to guarantee the participant's anonymity. 
The collected data were typed in an Excel worksheet, using double data entry, for analysis in Statistical Package for Social Science, version 15.0 (SPSS). The analysis considered the scores for two professional groups, i.e. nursing auxiliaries/technicians and nurses, instead of isolated scores for each subject. Variables related to socio-demographic and educational characteristics were summarized and descriptively presented through frequency distribution, with absolute and relative figures. For some variables, means and their respective standard deviations were also presented. Chi-square or Fisher's exact test were used to associate qualitative variables. To correlate quantitative variables, Pearson's correlation test was used. To check for possible differences between the mean correct answer percentages on the knowledge test between professional categories, Student's t-test for two independent samples was applied. Significance was set at $\alpha=0.05$ in all statistical tests.

\section{Results}

Research participants were 386 nursing team members, with 250 nursing auxiliaries/technicians (13\% losses) and 136 nurses (14\% losses). Losses in data collection remained below expected levels and involved: employees on holiday, health leave, maternity leave and medical leave of absence, transfer to sectors not included in the study, retirement or resignation and refusal to participate in the research. The participants' distribution according to socio-demographic characteristics is shown in Table 1.

Table 1 - Distribution of research participants according to socio-demographic characteristics. Ribeirão Preto, 2009

\begin{tabular}{|c|c|c|c|c|c|c|}
\hline \multirow{2}{*}{$\begin{array}{l}\text { Socio-demographic } \\
\text { characteristics }\end{array}$} & \multicolumn{2}{|c|}{$\begin{array}{l}\text { Nursing auxiliaries/technicians } \\
(250)\end{array}$} & \multicolumn{2}{|c|}{$\begin{array}{c}\text { Nurses (BSN) } \\
(136) \\
\end{array}$} & \multicolumn{2}{|c|}{$\begin{array}{l}\text { Total } \\
(386)\end{array}$} \\
\hline & $\mathbf{n}$ & $\%$ & $\mathbf{n}$ & $\%$ & $\mathbf{n}$ & $\%$ \\
\hline \multicolumn{7}{|l|}{ Age in Years } \\
\hline$<30$ & 46 & 18.4 & 36 & 26.5 & 82 & 21.2 \\
\hline $30 \vdash 40$ & 100 & 40.0 & 40 & 29.4 & 140 & 36.3 \\
\hline $40 \vdash 50$ & 74 & 29.6 & 43 & 31.6 & 117 & 30.3 \\
\hline $50 \vdash 60$ & 22 & 8.8 & 14 & 10.3 & 36 & 9.3 \\
\hline$\geq 60$ & 3 & 1.2 & 0 & 0 & 3 & 0.8 \\
\hline No answer & 5 & 2.0 & 3 & 2.2 & 8 & 2.1 \\
\hline Total & 250 & 100 & 136 & 100 & 386 & 100 \\
\hline \multicolumn{7}{|l|}{ Sex } \\
\hline Female & 205 & 82.3 & 124 & 91.2 & 329 & 85.5 \\
\hline Male & 44 & 17.7 & 12 & 8.8 & 56 & 14.5 \\
\hline Total & $249^{*}$ & 100 & 136 & 100 & $385^{\star}$ & 100 \\
\hline \multicolumn{7}{|c|}{ Time since professional education (years) } \\
\hline$<05$ & 16 & 6.4 & 12 & 8.8 & 28 & 7.3 \\
\hline $05 \vdash 10$ & 70 & 28.0 & 54 & 39.7 & 124 & 32.1 \\
\hline $10 \vdash 15$ & 94 & 37.6 & 27 & 19.9 & 121 & 31.3 \\
\hline $15 \vdash 20$ & 36 & 14.4 & 19 & 14.0 & 55 & 14.3 \\
\hline $20 \vdash 25$ & 13 & 5.2 & 6 & 4.4 & 19 & 4.9 \\
\hline$\geq 25$ & 9 & 3.6 & 15 & 11.0 & 24 & 6.2 \\
\hline No answer & 12 & 4.8 & 3 & 2.2 & 15 & 3.9 \\
\hline Total & 250 & 100 & 136 & 100 & 386 & 100 \\
\hline \multicolumn{7}{|c|}{ Time working in the hospital (years) } \\
\hline$<05$ & 72 & 28.8 & 45 & 33.1 & 117 & 30.3 \\
\hline $05 \vdash 10$ & 73 & 29.2 & 37 & 27.2 & 110 & 28.5 \\
\hline $10 \vdash 15$ & 62 & 24.8 & 14 & 10.3 & 76 & 19.7 \\
\hline $15 \vdash 20$ & 16 & 6.4 & 10 & 7.4 & 26 & 6.7 \\
\hline $20 \vdash 25$ & 14 & 5.6 & 21 & 15.4 & 35 & 9.1 \\
\hline$\geq 25$ & 12 & 4.8 & 9 & 6.6 & 21 & 5.4 \\
\hline No answer & 1 & 0.4 & 0 & 0 & 1 & 0.3 \\
\hline Total & 250 & 100 & 136 & 100 & 386 & 100 \\
\hline
\end{tabular}

* Considering only participants who answered the items.

As for age, most of the professionals (36.3\%) were between 30 and 40 years old. The mean age of nursing auxiliaries/technicians was 38.5 years ( $S D=8.9$ years) and of nurses 37.8 years ( $S D=8.9$ years). As for gender, women were more frequent $(85.3 \%)$ in both professional groups, with a statistical association between being nurse and female $(p=0.019)$. 
Time since professional education was shorter for nursing auxiliaries/technicians (mean 11.8 years, $\mathrm{SD}=5.9$ years) than for nurses (mean 12.1 years, $\mathrm{SD}=7.6$ years). The same was true for time working in the hospital (mean 9.6 years, $S D=7.1$ years) in comparison with the nurses (mean 10.4 years and $S D=8.5$ years).

Regarding global test results, the mean score for nursing auxiliaries/technicians was $73.6 \%$ of correct answers $(S D=9.8 \%)$ and for nurses $79.4 \%(S D=8.3 \%)$. Student's t-test showed a statistically significant difference $(p=0.000)$.

The professionals' results on the PU assessment and classification areas of the knowledge test are shown in Table 2.

Table 2 - Percentage of correct answers by research participants on the knowledge test, according to items on pressure ulcer assessment and classification. Ribeirão Preto, 2009

\begin{tabular}{|c|c|c|c|c|c|c|c|}
\hline & \multirow[t]{2}{*}{ Items about pressure ulcer assessment and classification } & \multicolumn{2}{|c|}{$\begin{array}{l}\text { Nursing auxiliaries/ } \\
\text { technicians } \\
(250)\end{array}$} & \multicolumn{2}{|c|}{$\begin{array}{l}\text { Nurses (BSN) } \\
\quad(136)\end{array}$} & \multicolumn{2}{|c|}{$\begin{array}{l}\text { Total } \\
(386)\end{array}$} \\
\hline & & $\mathbf{n}$ & $\%$ & $\mathbf{n}$ & $\%$ & $n$ & $\%$ \\
\hline 1 & Stage I pressure ulcers are defined as nonblanchable erythema. ( $T$ ) & 198 & 79.2 & 113 & 83.1 & 311 & 80.6 \\
\hline 6 & $\begin{array}{l}\text { A stage III pressure ulcer is a partial thickness skin loss involving } \\
\text { the epidermis and/or dermis. }(F)\end{array}$ & 75 & 30.0 & 68 & 50.0 & 143 & 37.0 \\
\hline 9 & $\begin{array}{l}\text { Stage IV pressure ulcers are a full thickness skin loss with } \\
\text { extensive destruction, tissue necrosis, or damage to muscle, bone, } \\
\text { or supporting structure. (T) }\end{array}$ & 212 & 84.8 & 128 & 94.1 & 340 & 88.1 \\
\hline 20 & Stage II pressure ulcers are a full thickness skin loss. (F) & 70 & 28.0 & 44 & 32.4 & 114 & 29.5 \\
\hline 31 & Pressure ulcers are sterile wounds. (F) & 210 & 84.0 & 112 & 82.4 & 322 & 83.4 \\
\hline 32 & A pressure ulcer scar will break down faster than unwounded skin. $(T)$ & 199 & 79.6 & 114 & 83.8 & 313 & 81.1 \\
\hline 33 & A blister on the heel is nothing to worry about. $(F)$ & 228 & 91.2 & 125 & 91.9 & 353 & 91.5 \\
\hline 38 & $\begin{array}{l}\text { Stage II pressure ulcers may be extremely painful due to exposure } \\
\text { of nerve endings. }(T)\end{array}$ & 144 & 57.6 & 74 & 54.4 & 218 & 56.5 \\
\hline
\end{tabular}

$T=$ true; $F=$ false

On the items related to PU assessment and classification, participants obtained $90 \%$ or more of correct answers for one item (number 33), between 70 and $89.9 \%$ on four items $(1,9,31$ and 32$)$ and below $70 \%$ on three items (numbers 6, 20 and 38). On one of these items (number 38), nursing auxiliaries/technicians scored higher (57.6\%) than nurses (54.4\%). The lowest number of correct answers (29.5\%) was for the item related to stage II PU description.

Table 3 displays results for the 33 test items on PU prevention.

Table 3 - Percentage of correct answers by research participants on the knowledge test, according to items on pressure ulcer prevention. Ribeirão Preto, 2009

\begin{tabular}{|c|c|c|c|c|c|c|c|}
\hline & \multirow[t]{2}{*}{ Items about pressure ulcer prevention } & \multicolumn{2}{|c|}{$\begin{array}{c}\text { Nursing auxiliaries/ } \\
\text { technicians } \\
(250)\end{array}$} & \multicolumn{2}{|c|}{$\begin{array}{l}\text { Nurses (BSN) } \\
\quad(136)\end{array}$} & \multicolumn{2}{|c|}{$\begin{array}{l}\text { Total } \\
(386)\end{array}$} \\
\hline & & $\mathbf{n}$ & $\%$ & $\mathbf{n}$ & $\%$ & $\mathbf{n}$ & $\%$ \\
\hline 2 & $\begin{array}{l}\text { Risk factors for development of pressure ulcers are immobility, } \\
\text { incontinence, impaired nutrition, and altered level of consciousness. (T) }\end{array}$ & 211 & 84.4 & 123 & 90.4 & 334 & 86.5 \\
\hline 3 & $\begin{array}{l}\text { All individuals at-risk for pressure ulcers should have a systematic } \\
\text { skin inspection at least once a week. }(F)\end{array}$ & 138 & 55.2 & 85 & 62.5 & 223 & 57.8 \\
\hline 4 & $\begin{array}{l}\text { Hot water and soap may dry the skin and increase the risk for } \\
\text { pressure ulcers. }(T)\end{array}$ & 121 & 48.4 & 77 & 56.6 & 198 & 51.3 \\
\hline 5 & It is important to massage bony prominences. $(\mathrm{F})$ & 78 & 31.2 & 75 & 55.1 & 153 & 39.6 \\
\hline 7 & $\begin{array}{l}\text { All individuals should be assessed on admission to a hospital for } \\
\text { risk of pressure ulcer development. }(T)\end{array}$ & 228 & 91.2 & 131 & 96.3 & 359 & 93.0 \\
\hline 8 & $\begin{array}{l}\text { Corn starch, creams, transparent dressings, and hydrocolloid } \\
\text { dressings do protect against the effects of friction. }(\mathrm{T})\end{array}$ & 231 & 92.4 & 124 & 91.2 & 355 & 92.0 \\
\hline 10 & $\begin{array}{l}\text { An adequate dietary intake of protein and calories should be } \\
\text { maintained during illness or hospitalization. }(T)\end{array}$ & 225 & 90.0 & 131 & 96.3 & 356 & 92.2 \\
\hline 11 & Persons confined to bed should be repositioned every 3 hours. (F) & 150 & 60.0 & 97 & 71.3 & 247 & 64.0 \\
\hline 12 & A turning schedule should be used for patients at risk. (T) & 219 & 87.6 & 128 & 94.1 & 347 & 89.9 \\
\hline
\end{tabular}


Table 3 - (continuation)

\begin{tabular}{|c|c|c|c|c|c|c|c|}
\hline & \multirow[t]{2}{*}{ Items about pressure ulcer prevention } & \multicolumn{2}{|c|}{$\begin{array}{l}\text { Nursing auxiliaries/ } \\
\text { technicians } \\
(250)\end{array}$} & \multicolumn{2}{|c|}{$\begin{array}{l}\text { Nurses (BSN) } \\
(136)\end{array}$} & \multicolumn{2}{|c|}{$\begin{array}{l}\text { Total } \\
(386)\end{array}$} \\
\hline & & $n$ & $\%$ & $\mathbf{n}$ & $\%$ & $\mathbf{n}$ & $\%$ \\
\hline 13 & $\begin{array}{l}\text { Heel protectors as gloves filled with water or air relieve pressure on } \\
\text { the heels. (F) }\end{array}$ & 94 & 37.6 & 91 & 66.9 & 185 & 47.9 \\
\hline 14 & $\begin{array}{l}\text { Air/water donut devices/ring cushions help to prevent pressure } \\
\text { ulcers. (F) }\end{array}$ & 65 & 26.0 & 71 & 52.2 & 136 & 35.2 \\
\hline 15 & $\begin{array}{l}\text { In a side lying position, a person should be at a } 30 \text { degree angle } \\
\text { with the bed. ( } T \text { ) }\end{array}$ & 94 & 37.6 & 50 & 36.8 & 144 & 37.3 \\
\hline 16 & $\begin{array}{l}\text { The head of the bed should be maintained at the lowest degree of } \\
\text { elevation (hopefully, no higher than a } 30 \text { degree angle) consistent } \\
\text { with medical condition. ( } \mathrm{T} \text { ) }\end{array}$ & 68 & 27.2 & 39 & 28.7 & 107 & 27.7 \\
\hline 17 & $\begin{array}{l}\text { A person who cannot move self should be repositioned while sitting } \\
\text { in a chair every two hours. (F) }\end{array}$ & 72 & 28.8 & 36 & 26.5 & 108 & 28.0 \\
\hline 18 & $\begin{array}{l}\text { Persons, who can be taught, should shift their weight every } 15 \\
\text { minutes while sitting a chair. }(T)\end{array}$ & 154 & 61.6 & 99 & 72.8 & 253 & 65.5 \\
\hline 19 & Chair-bound persons should be fitted for a chair cushion. ( $T$ ) & 230 & 92.0 & 122 & 89.7 & 352 & 91.2 \\
\hline 21 & The skin should remain clean and dry. ( $\mathrm{T}$ ) & 245 & 98.0 & 134 & 98.5 & 379 & 98.2 \\
\hline 22 & $\begin{array}{l}\text { Continuous prevention measures do not need to be used when an } \\
\text { individual has already a pressure ulcer. }(F)\end{array}$ & 227 & 90.8 & 131 & 96.3 & 358 & 92.7 \\
\hline 23 & Turning or lift sheets should be used to turn or transfer patients. ( $\mathrm{T}$ ) & 242 & 96.8 & 131 & 96.3 & 373 & 96.6 \\
\hline 24 & $\begin{array}{l}\text { Dependent patients should be repositioned or transferred by two } \\
\text { individuals. }(\mathrm{T})\end{array}$ & 248 & 99.2 & 130 & 95.6 & 378 & 97.9 \\
\hline 25 & $\begin{array}{l}\text { Rehabilitation should be instituted if consistent with the patient's } \\
\text { overall goals of therapy. }(T)\end{array}$ & 226 & 90.4 & 131 & 96.3 & 357 & 92.5 \\
\hline 26 & $\begin{array}{l}\text { All bed or chair-bound individuals should be assessed for pressure } \\
\text { ulcer risk. }(T)\end{array}$ & 246 & 98.4 & 135 & 99.3 & 381 & 98.7 \\
\hline 27 & $\begin{array}{l}\text { Patient/Caregiver should be educated about the causes and risk } \\
\text { factors for pressure ulcer development. }(\mathrm{T})\end{array}$ & 247 & 98.8 & 133 & 97.8 & 380 & 98.4 \\
\hline 28 & $\begin{array}{l}\text { Bony prominences may be kept with direct contact with one } \\
\text { another. }(F)\end{array}$ & 235 & 94.0 & 130 & 95.6 & 365 & 94.6 \\
\hline 29 & $\begin{array}{l}\text { Every person assessed to be at risk for developing pressure ulcers } \\
\text { should be placed on a pressure-reducing bed surface. }(T)\end{array}$ & 218 & 87.2 & 123 & 90.4 & 341 & 88.3 \\
\hline 30 & Skin, macerated from moisture, tears more easily. (T) & 230 & 92.0 & 130 & 95.6 & 360 & 93.3 \\
\hline 34 & $\begin{array}{l}\text { A good way to decrease pressure on the heels is to elevate them off } \\
\text { the bed. }(T)\end{array}$ & 224 & 89.6 & 124 & 91.2 & 348 & 90.2 \\
\hline 35 & $\begin{array}{l}\text { All care given to prevent or treat pressure ulcers do not need to be } \\
\text { documented. (F) }\end{array}$ & 237 & 94.8 & 131 & 96.3 & 368 & 95.3 \\
\hline 36 & $\begin{array}{l}\text { Shear is the force which occurs when the skin sticks to a surface } \\
\text { and the body slides. }(T)\end{array}$ & 77 & 30.8 & 98 & 72.1 & 175 & 45.3 \\
\hline 37 & Friction may occur when moving a person up in bed. $(T)$ & 224 & 89.6 & 129 & 94.9 & 353 & 91.5 \\
\hline 39 & $\begin{array}{l}\text { For persons who have incontinence, skin cleaning should occur at } \\
\text { the time of soiling and routine intervals. }(T)\end{array}$ & 230 & 92.0 & 120 & 88.2 & 350 & 90.7 \\
\hline 40 & Educational programs may reduce the incidence of pressure ulcers. $(T)$ & 246 & 98.4 & 135 & 99.3 & 381 & 98.7 \\
\hline 41 & $\begin{array}{l}\text { Hospitalized individuals should be assessed for pressure ulcers risk } \\
\text { only once. }(F)\end{array}$ & 226 & 90.4 & 127 & 93.4 & 353 & 91.5 \\
\hline
\end{tabular}

$\mathrm{T}=$ true; $\mathrm{F}=$ false

On the 33 test items regarding PU prevention, participants scored more than $90 \%$ on 19 (57.6\%) items, between 70 and $89.9 \%$ on three $(9.1 \%)$, between 50 and $69.9 \%$ on four (12.1\%) and less than $50 \%$ on seven $(21.2 \%)$ items.

Aspects on which both professional groups had the lowest percentage of correct answers were related to the use of massage (39.6\%), air/water donut devices or ring cushions (35.2\%), water or air-filled gloves (47.9\%) and positioning the patient with regard to the head of the bed $(27.7 \%)$, the time period for repositioning while sitting in a chair (28\%) and side lying positioning $(37.3 \%)$.
Nursing auxiliaries/technicians' percentage of correct answers decreased with the time since professional education ( $r=-0.170 ; p=0.009)$, and also with the time working in the hospital $(r=-0.125 ; p=0.049)$. For nurses (BSN), on the other hand, the correlation found between the percentage of correct answers and those variables was not statistically significant.

\section{Discussion}

Nursing team members are responsible for direct and continuous care related to PU prevention and treatment. For nursing to achieve quality care, its practice 
needs to be based on the best evidence regarding the theme. Knowledge about this evidence on PU should be part of all nursing professionals' knowledge base. Education programs should focus not only on prevention and treatment interventions and ulcer characteristics, but also on the legal implications of correct patient file documentation ${ }^{(1,6,17)}$.

Considering all correct answers, test results showed that both nurses (mean 79.4\%) and nursing auxiliaries/ technicians' (mean 73.6\%) knowledge was insufficient. For knowledge to be considered adequate, participants were expected to give $90 \%$ or more of correct answers on the test items ${ }^{(12)}$. It was identified, however, that only four nursing auxiliaries/technicians (16\%) and 16 nurses $(11.8 \%)$ correctly answered $90 \%$ or more of the items, highlighting the need to update the team's knowledge on current evidence supporting PU prevention.

These data revealed that both professional categories present knowledge deficits in some areas related to the theme, although nursing auxiliaries/ technicians have less knowledge.

In the study in which the knowledge test used in this research was initially developed, the mean percentage of correct answers was identified at $71.7 \%$, involving 228 nurses from two American hospitals. Knowledge levels were significantly higher among professionals who had attended some lecture or read some article on the theme the year before ${ }^{(11)}$.

In another study that used the same knowledge test as in the preliminary version, the mean percentage of correct answers by 75 Intensive Care Unit (ICU) nurses from two American hospitals was $71.3 \%$. Test scores were not associated with the time since graduation or the professional's sage. They identified that the test score related to the ulcer description was higher among professionals who had attended some lecture the year before or had read articles on the theme ${ }^{(12)}$.

In Brazil, a study involving nursing students from a public university used the preliminary version of Pieper's PUKT adapted to Portuguese and showed that the mean percentage of correct answers was $67.7 \%$. Test scores were significantly higher among students who participated in extracurricular activities or used the Internet to seek information about PU(13).

Another study with 25 nurses at a private hospital also used the preliminary version of Pieper's PUKT. The mean percentage of correct answers was $70.6 \%$. Test scores were significantly higher among nurses who participated in continuing education activities the institution offered ${ }^{(14)}$.
In Canada, researchers used the same Pieper's PUKT, adapting the preliminary version to 53 items with a view to assessing professionals' knowledge before and after an educative workshop. The nurses' percentage of correct answers was $42.3 \%$ on the pretest, $69.5 \%$ on the post-test (after the educative approach) and $60.2 \%$ on the post-test, three months later. Nursing technicians, on the other hand, scored $34.9 \%$ on the pretest, $61.4 \%$ on the post-test (after the educative approach) and $56.3 \%$ on the post-test three months later. They concluded that the knowledge test scores were better than the pretest at the two times after the workshop, although results of the second application declined. The nurses' scores were higher than the nursing technicians at all times ${ }^{(15)}$.

In the United States, a study involving nursing from the urban and rural areas of Montana used the preliminary version of the Pieper's PUKT, and the mean test score was $78 \%$. When analyzing the impact of nurses' certification on clinical practice, the authors identified that those with a certificate in wound treatment scored $89 \%$, while nurses certified in another specialty scored $78 \%$ and nurses without certification $76.5 \%$. Differences in knowledge test scores favoring nurses certified in wound care $(p<0.000)$ made the authors recommend that institutions consider these factors when planning wound care teams and include certified professionals ${ }^{(5)}$.

And a study carried out in Spain which involving nurses and nursing technicians used a 37-item questionnaire, developed according to the recommendations published by the Grupo Nacional para el Estudio y Asesoramiento en Ulceras por presión y heridas crónicas (GNEAUPP) in 1995, with a view to assessing these professionals' knowledge level on existing PU prevention and treatment guidelines, the implementation level of this knowledge in clinical practice and educational and professionals factors influencing knowledge and practice. The general coefficient of correct answers on the knowledge test was $78 \%$, with $79.1 \%$ for preventive interventions and $75.9 \%$ for treatment interventions ${ }^{(16)}$.

In a recent study carried out in New Zealand, the authors created a knowledge test on PU prevention, based on international guidelines and involving eight international experts on the theme. Using a modified Delphi technique and electronic communication, they reached a consensus on the questions' contents and on $76 \%$ of correct answers as a minimum competency level for nurses to pass the test. The test was used to assess the impact of an educative program, including an oral presentation with slides and discussion, taking approximately three hours, offered to ICU nurses. 
Measurements took place before, two and 20 weeks after the course. The nurses answered $84 \%$ of questions correctly before the course, $89 \%$ on the first assessment two weeks after and $85 \%$ on the second assessment after 20 weeks. Differences between results before and two weeks after the event were statistically significant $(p=0.003)$, but no difference was found when comparing the same subjects' results before and 20 weeks after the event $^{(18)}$.

The study carried out in Brazil to assess the impact of an educative intervention, using the adapted Pieper's PUKT ${ }^{(1)}$, identified $86.4 \%$ of correct answers $(S D=4.6 \%)$ by nurses in the pre-intervention phase, but no professional participated in the post-intervention assessment. Nursing auxiliaries and technicians scored $74.3 \%(\mathrm{SD}=14.8 \%)$ in the pre-intervention and $81.2 \%$ $(\mathrm{SD}=12.7 \%)$ in the post-intervention phase, held 20 weeks after the course. It was concluded that, for this group of professionals, the intervention collaborated to improve test results ${ }^{(1)}$.

The professionals' results in the present and earlier Brazilian and international studies demonstrate that knowledge gaps exist and persist, despite technicalscientific advances on the theme and available guidelines with recommendations for practice ${ }^{(1,5,11-16)}$.

The use of risk assessment instruments for PU development, like the Braden scale, identifies patients at risk and associated risk factors, helping nurses to make decisions on planning subsequent prevention measures for each patient to adopt. Knowledge about these scales and their use should be a priority in education and permanent education programs ${ }^{(2)}$.

As PU development during hospitalization is an important healthcare quality indicator, the adoption of a prevention system is expected as a strategy to mitigate the problem. Successful PU prevention depends on health professionals' knowledge and skills regarding the theme, mainly nursing professionals who deliver direct and continuing patient care. It is necessary, however, to understand the individual and institutional factors influencing professionals' knowledge and use of evidence, so that strategies can be planned and used at the institutions.

In countries where PU is considered a health and nursing service quality indicator, occurrence levels are assessed in terms of incidence and strategic educational planning is developed with a view to an action plan to use recommendations for evidence-based practice. The plan also includes workshops for nurse managers and service directors, emphasizing leadership development and characteristics of institutional cultural change processes, so that resistance is reduced(19-20). In Brazil, this kind of institutional initiatives are not common yet, but necessary, considering the multifactorial nature of the problem and its range.

\section{Conclusions}

The mean percentage of correct answers on the knowledge test for nurses (mean $=79.4 \%, S D=8.3 \%$ ) and for nursing auxiliaries/technicians (mean $=73.6 \%$, $\mathrm{SD}=9.8 \%$ ) showed knowledge deficits about the theme. Some areas stand out that need greater focus on continuing professional education activities.

The nursing auxiliaries/technicians' percentage of correct answers decreased with the time since professional education and with time working in the hospital, with a statistically significant correlation in both cases. In the nurses' group, no statistically significant correlation was found between the percentage of correct answers on the test and the time since professional education ( $r=-0.113 ; p=0.193$ ) or time working in the hospital ( $r=-0.059 ; p=0.496)$.

These study results can help to identify knowledge deficits among nursing team members and, in the context under analysis, guide strategic planning for disseminating and adopting prevention measures that are considered innovations.

\section{References}

1. Fernandes LM, Caliri MHL, Haas VJ. Efeito de intervenções educativas no conhecimento dos profissionais de enfermagem sobre prevenção de úlceras por pressão. Acta Paul Enferm. 2008;21(2):305-11.

2. Fernandes LM, Caliri MHL. Uso da escala de Braden e de Glasgow para identificação do risco para úlceras de pressão em pacientes internados em centro de terapia intensiva. Rev. Latino-Am. Enfermagem. 2008;16(6):973-8.
3. Rogenski NMB, Santos VLCG. Estudo sobre a incidência das úlceras por pressão em um hospital universitário. Rev. LatinoAm. Enfermagem. 2005;13(4):474-80.

4. Duimel-Peeters IGP, Hulsenboom MA, Berger MPF, Snoeckx LHEH, Halfens RJG. Massage to prevent pressure ulcers: knowledge, beliefs and practice. A cross-sectional study among nurses in the Netherlands in 1991 and 2003. J Clin Nurs. $2006 ; 15(4): 428-35$. 
5. Zulkowski K, Ayello EA, Wexler S. Certification and education: do they affect pressure ulcer knowledge in nursing? Adv Skin Wound Care. 2007;20(1):34-8.

6. Santos VLCG, Azevedo MAJ, Silva TS, Carvalho VMJ, Carvalho VF. Adaptação transcultural do pressure ulcer scale for healing (PUSH) para a língua portuguesa. Rev. Latino-Am. Enfermagem. 2005;13(3):305-13.

7. Bergstrom N, Allman RM, Carlson CE, Eaglstein W, Frantz $\mathrm{RA}$, Garber $\mathrm{SL}$, et al. Pressure ulcers in adults: prediction and prevention. Clinical Practice Guideline. Number 3. Rockville (MD): US Department of Health and Human Services/Public Health Service/Agency for Health Care Policy and Research (AHCPR); 1992. Publication n. 95-0047.

8. Registered Nurses Association of Ontorio (RNAO). Risk assessment \& prevention of pressure ulcers [Internet]. Toronto (CA): RNAO; 2005 [acesso 22 jun 2009]. 80 p. Disponível em: http://www.rnao.org/Storage/12/638_BPG_Pressure_Ulcers_ v2.pdf

9. Rycroft-Malone J, McIness E. Pressure ulcer risk assessment and prevention. Clinical practice guidelines. London (GB): Royal College of Nursing (RCN); 2000. Technical report.

10. Wound, Ostomy, and Continence Nurses Society (WOCN). Guideline for prevention and management of pressure ulcers. WOCN clinical practice guidelines series. Number 2. Glenview (IL): WOCN; 2003.

11. Pieper B, Mott M. Nurses' knowledge of pressure ulcer prevention, stating, and description. Adv Wound Care. $1995 ; 8(3): 34-48$.
12. Pieper B, Mattern JC. Critical care nurses' knowledge of pressure ulcer prevention, stating and description. Ostomy/ Wound Manage. 1997;43(2):22-31.

13. Caliri MHL, Miyazaki MY, Pieper B. Knowledge of pressure ulcers by undergraduate nursing students in Brazil. Ostomy/ Wound Manage. 2003;49(3):54-63.

14. Rangel EML, Caliri MHL. Conhecimento de enfermagem de um hospital geral sobre a prevenção e avaliação da úlcera por pressão. Rev Paul Enferm. 2004;23(2):123-9.

15. Sinclair L, Berwiczonek H, Thurston N, Butler S, Bulloch $G$, Ellery $C$, et al. Evaluation of an evidence-based education program for pressure ulcer prevention. J Wound, Ostomy, and Continence Nurs. 2004;31(1):43-50.

16. Pancarbo-Hidalgo PL, García-Fernández FP, López-Medina IS, López-Ortega J. Pressure ulcer care in Spain: nurses' knowledge and clinical practice. J Adv Nurs. 2007;58(4):327-38.

17. Nogueira PC, Caliri MHL, Haas VJ. Perfil de pacientes com lesão traumática da medula espinhal e ocorrência de úlcera de pressão em um hospital universitário. Rev. Latino-Am. Enfermagem. 2006;14(3):372-7.

18. Tweed C, Tweed M. Intensive care nurses' knowledge of pressure ulcers: development of an assessment tool and effect of an education program. Am J Critical Care. 2008;17(24):338-46. 19. Rycroft-Malone J. Evidence-informed practice: from individual to context. J Nurs Manage. 2008;16(4):404-8.

20. Ewers KM, Coker CT, Bajnok I, Denker AL. A collaborative curricular model for implementing evidence-based nursing in a critical care setting. Critical Care Nurs Clin North Am. $2008 ; 20(4): 423-34$ 